as in other holometabolans. This hypothesis is supported by the presence of a possible remnant of Bolwig's organ in advanced dipteran imagines $[4,5]$. If so, development of higher dipteran stemmata would be in accordance with a mode common to many holometabolans.

Moreover, these findings suggest that the basic organization of the stemmata's optic neuropils is maintained among primitive and advanced dipterans. Stemmata appear to possess a first and a second larval optic neuropil in close relation with the imaginal neuropils. As revealed in comparative works (for review, see [11]), stemmata are modified ommatidia. Therefore, similarities between both larval and imaginal optic neuropils are to be expected and hence should be interpreted as a "consecutive homology" [11].

Regarding this, it is most striking that even in imaginal trichopterans and in larval lepidopterans a similar projection pattern of fibers originating from stemmata was found $[9,12]$. These fibers terminate within a "larval" lamina and a "larval" medulla as shown for Chaoborus. Though it is not known if a third larval optic neuropil may be present, it is suggested that larval and imaginal parts of the optic lobes have a homologous arrangement not only in dipterans, but also in various other holometabolans.

This study was partly supported by a grant from the Landesgraduiertenförderung Baden-Württemberg given to R. R. Melzer. We thank K.-F. Fischbach for useful comments on the manuscript and J. D. Plant for improving the English.

Received May 28, 1990
1. Constantineanu, M.: Zool. Jb. Anat. $52,253(1930)$

2. Melzer, R. R., Paulus, H. F.: Z. zool. Syst. Evol.-forsch. 27, 200 (1989)

3. Tix, S., Minden, J. S., Technau, G. M.: Development 105, 739 (1989)

4. Hofbauer, A., Buchner, E.: Naturwissenschaften 76, 335 (1989)

5. Nässel, D. R., Holmqvist, M. H., Hardie, R. C., Hakanson, R., Sundler, F.: Cell Tiss. Res. 253, 639 (1988)

6. Fischbach, K.-F., Dittrich, A. P. M.: ibid. 258, 441 (1989)

7. Campos-Ortega, J. A., Strausfeld, N. J.: Z. Zellforsch. 124, 561 (1972)

8. Strausfeld, N. J., Obermayer, M.: J, Comp. Physiol. 110, 1 (1976)

9. Hagberg, M.: Cell Tiss. Res. 245, 643 (1986)

10. Steller, H., Fischbach, K.-F., Rubin, G. M.: Cell 50, 1139 (1987)

11. Paulus, H. F.: Zool. Beitr. N. F. 32, 437 (1989)

12. Ichikawa, T., Tateda, H.: J. Neurocytol. 13, 227 (1984)
Naturwissenschaften 77, $394-398$ (1990) (C) Springer-Verlag 1990

\section{The Relative Contribution of Retinal and Cortical Mechanisms to Simultaneous Contrast}

\author{
B. Lange-Malecki, J. Poppinga and O. D. Creutzfeldt \\ Max-Planck-Institut für Biophysikalische Chemie, Abteilung Neurobiologie, \\ D-3400 Göttingen-Nikolausberg
}

Simultaneous brightness and color contrasts are fundamental properties of the visual system and allow it to function over a wide range of illumination conditions. For adjacent contrast areas lateral inhibitory interactions between center and surround regions of receptive fields of single retinal ganglion cells play a major role [1], but for distant regions longer ranging interactive processes must be involved. These are usually located in horizontal neuronal systems in the retina, but there is also evidence that intraocular stray light plays a major role [2]. On the other hand, lateral inhibition between adjacent regions in a net of neurons is not only a property of the respective sensory periphery, in our case the retina, but is found at all levels of the visual pathways, i.e., in the lateral geniculate body [3] and in the cortex [4]. Such central inhibitory interactions are essential for stereoscopic depth perception, as documented neurophysiologically by the inhibitory interaction between binocular stimuli of unproper disparity [5]. They do not explain, on the other hand, the monocular vs. binocular brightness constancy, that is, the fact that the brightness of the visual environment is about the same when we look through one or both eyes since the population response of cortical neurons to contrasts is increased by a factor of $1.5-2.0$ when both eyes are open as compared to monocular stimulation [6].

The question arises to what extent these central inhibitory interactions might contribute to the contrast phenomena in perception. In classical visual psychophysics, it was clearly stated by Mach [7] that retinal mechanisms are sufficient for brightness and color contrast and he offered a model which is still valid, in its basic aspects. Also, Hering [8] located the mechanisms responsible for simultaneous contrast in the retina, but Helmholtz [9] argued that brightness and color contrasts are largely a matter of "psychological judgement" and thus referred it to higher levels of the nervous system. The question was revived in recent years, when Land et al. [10] found casuistic evidence from a patient with transsection of the corpus callosum that color contrast phenomena might be indeed of cortical origin, while Pöppel [11] demonstrated in a patient with a circumscribed skotoma that peripheral mechanisms in the retina might be sufficient.

We tried to separate the retinal and the central contribution to brightness contrast by taking advantage of the fact that the inputs from the two eyes come together only at the cortical level. We measured the contrast effects of surround light on a central test spot when both center and sourround light were 
offered to one or both eyes simultaneously (monoptic or binocular situation) and compared it to the contrast effects when center light was offered to one but surround light to the other eye (dichoptic situation).

Dichoptic brightness and color contrasts have been known to sensory physiologists for a long time [12], and summation (or averaging) of the inputs from the two eyes has been demonstrated for color [13] as well as for brightness [14]. The investigation of dichoptic vision is hampered, however, by binocular rivalry, by which the input from one or the other eye is suppressed when the visual stimuli to the two eyes are not identical. This can be largely overcome by adding a fine grid of contrast lines to the stimulus to one eye. Now in most individuals, the visual image to this eye is not suppressed by interocular rivalry [15]. In addition, regular alternation between the dichoptic and the binocular or monoptic viewing condition further helps to overcome ocular rivalry.

We report here on a comparison of the darkness induction in a small test field ( $1^{\circ}$ diameter) exerted by a sourround field of $1^{\circ}$ inner and $4.5^{\circ}$ outer diameter at various intensities (first experiment), and on the reduction of contrast sensitivity in a central $3^{\circ}$ field by surrounds (inner diameter $3^{\circ}$, outer diameter $9^{\circ}$ ) of different intensities in the binocular and the dichoptic situation (second experiment). The first experiment was done on a phase difference haploscope [16], the second on a synoptophor [17]: Our results indicate that central mechanisms can produce darkness induction and sensitivity changes in a central test field but that these are smaller and appear to have a more limited range than the respective intraocular effects.

Figure 1 shows the darkness induction of a surround field at different intensities on a $1^{\circ}$ center light in the binocular (continuous line) and the dichoptic situation (broken line). The data are the means from four observers (vertical lines give the interindividual standard deviations). Only these four of seven subjects showed clear contrast effects in the dichoptic viewing condition. Two subjects did not indicate any brightness change of the central test field in the dichoptic situation (see Fig. 3 A, symbols 5 and 6) and one subject only
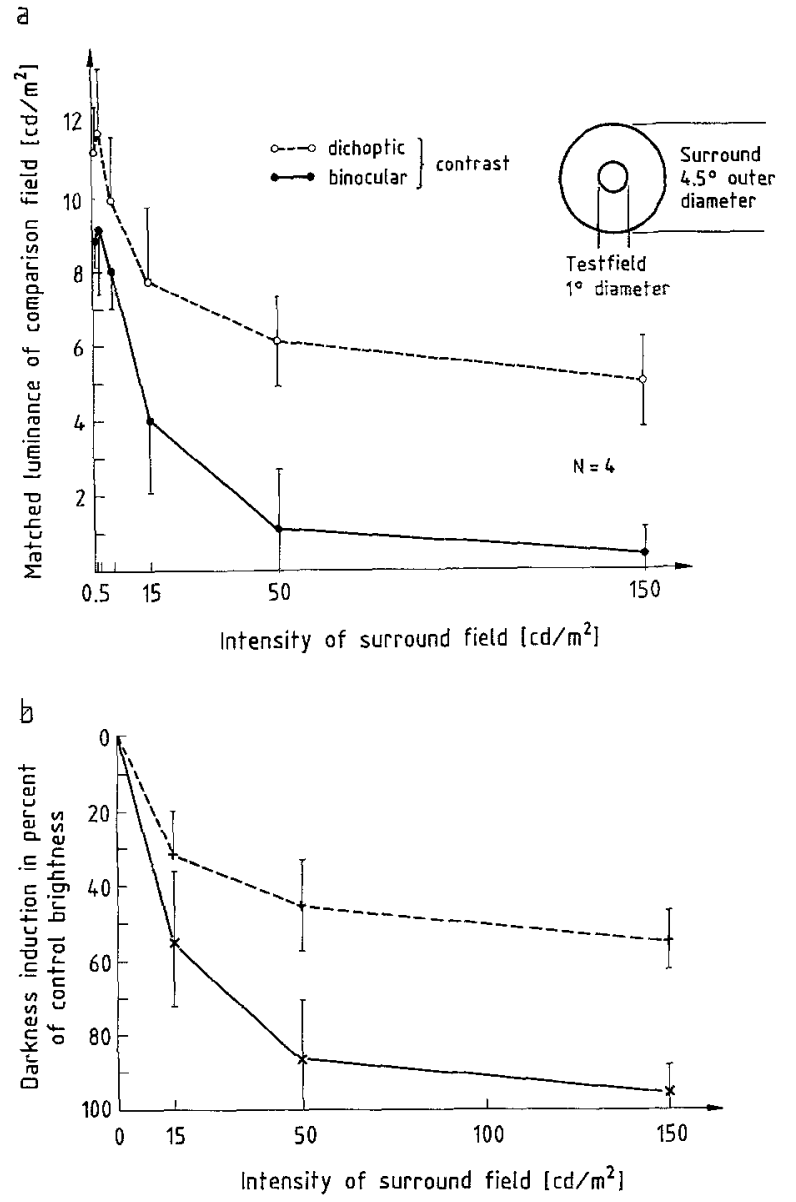

Fig. 1. Darkness induction by a surround field of various intensities in the binocular and dichoptic situation. Measurements were done on a phase difference haploscope [16] which allowed the exposure of both eyes to the same image or each eye separately with one or the other stimulus in $100 / \mathrm{s}$ alternations (for details of the experimental design, see [15]). Binocular rivalry was reduced by superimposing the test spot with a grid of fine contrast lines and by opening with shutters the view of both eyes for $1 \mathrm{~s}$ periods interrupted by $1 \mathrm{~s}$ during which the comparison spot was shown to both eyes in the same position as the test spot. The observer had to adjust the luminance of the comparison spot with a neutral density wedge in front of the projector so that it appeared as bright as the central test spot (matching procedure).

matched the surround intensity in the dichoptic situation. In Fig. 1A, it can be noted that the brightness match for the test field at the lowest surround intensity $\left(0.5 \mathrm{~cd} / \mathrm{m}^{2}\right.$ background) is by a factor of 1.27 higher in the dichoptic than in the binocular situation. This is due to the fact that during binocular viewing both eyes see the central test
When he was satisfied by his match, the luminance of the comparison spot was measured with a Spectra photometer. This procedure was repeated three times. Dichoptic experiments were repeated with one or the other eye exposed to the test spot and data from both eyes were pooled. A) Original data, B) the relative changes of brightness as a function of surround luminance. These data are averages with standard deviations from four observers out of seven (see text). In (B), the control value is set as 0 , and the relative amount of brightness reduction is given in $\%$. Observers were healthy persons of both sexes (age: $24-35$ years) with normal binocular vision and no or slight refraction anomalies which were fully corrected

spot all the time and are thus both adapted while during the dichoptic situation only one eye is exposed to the test spot, while the other only sees it during the matching period. In order to overcome this difficulty we calculated the relative changes of brightness of the test field for each observer at different surround conditions separately in the 

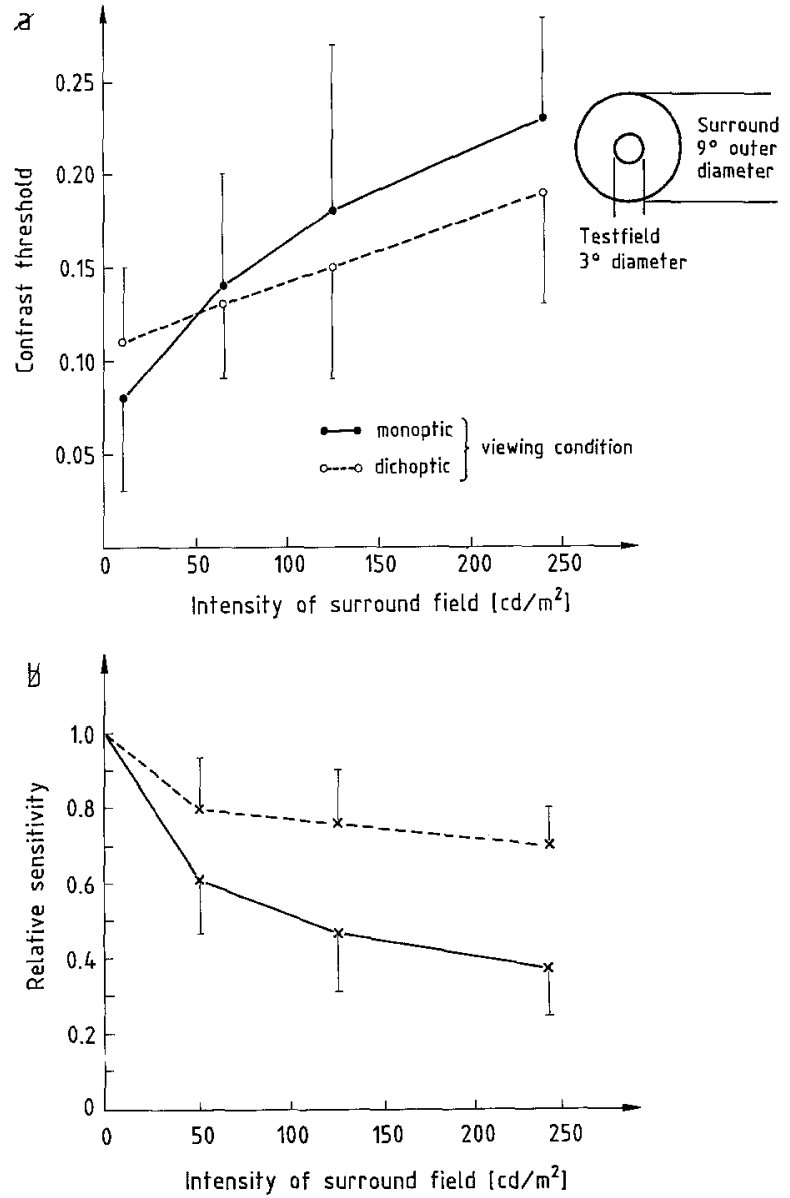

Fig. 2. Increase of contrast threshold as a function of surround intensity in the monoptic and dichoptic viewing condition. Data from six subjects. This experiment was done on a synoptophor [17]. Subjects looked with the right eye through a $3^{\circ}$ hole at a black/ white television screen, the luminance of which alternated at a rate of $1 \mathrm{~s}$, from a basic intensity of $10 \mathrm{~cd} / \mathrm{m}^{2}$ to a higher intensity. The amplitude of the intensity difference was changed at random in steps down to a minimum of 0.01 contrast. The subject had to indicate whether he saw a flickering at a given contrast setting. The contrast at which the observers answered $50 \%$ with yes

binocular and the dichoptic situation. The averages of these relative values are shown in Fig. 1B. The ordinate shows the darkness induction, the abscissa the luminance of the surround. These curves clearly demonstrate that the darkness induction is always larger in the binocular than in the dichoptic situation. The fraction dichoptic to binocular darkness induction varied, at all surround intensities and in all four observers, between 0.5 and 0.7 , with and $50 \%$ with no was taken as the contrast threshold. In the monoptic viewing situation, a circular field of $9^{\circ}$ outer diameter surrounded the $3^{\circ}$ hole through which the right eye looked at the television screen. In the dichoptic situation the left eye looked at a surround field of $3^{\circ}$ inner and $9^{\circ}$ outer diameter, the center of which was not illuminated, while the right eye only saw the flickering screen through the $3^{\circ}$ hole. A) Original data with the standard deviations, B) change of contrast thresholds relative to the first value determined at a surround of $10 \mathrm{~cd} / \mathrm{m}^{2}$

only one value below ( 0.22$)$ and one above (1.05) this range. The average of all dichoptic to monoptic quotients was $0.58 \pm 0.2$ or, in reciprocal terms, central mechanisms increase the effects by a factor of 1.72 .

As indicated by the large standard deviation in Fig. 1A, the darkness induction in the binocular as well as in the dichoptic situation showed considerable interindividual variation. On the other hand, there was a tendency that in the different observers the strength of darkness induction in the binocular and the dichoptic conditions was correlated $(r=0.69)$. This means, as shown in Fig. 3A, that values measured by one observer may overlap with those measured by another, but that for each observer brightness decreased with increasing surround intensity and that the binocular darkness induction was always larger than the dichoptic.

In the second experiment, we determined the change of contrast threshold at different surround intensities (see Fig. 2). This time, the surround effect in the dichoptic was compared with that in the monoptic viewing situation (only one eye sees the center and the surround). The contrast sensitivity in the center clearly decreases with increasing surround illumination in the monoptic as well as in the dichoptic viewing condition. Also, in this experiment the effect in the dichoptic situation was much less and, in addition, the interindividual variation was larger. But again, in each observer and at each intensity, the surround effect was larger in the monoptic than in the dichoptic situation (except for one value at the lowest surround intensity). This is shown in Fig. 3B, where the dichoptic (ordinate) and the monoptic (abscissa) surround effects under different contrast situations were plotted against each other. The correlation between both measurements was $r=0.7$. On the average, the surround effect in the monoptic situation was 4.6 times larger than that in the dichoptic situation (dichoptic to monoptic quotient $=$ 0.22 ), if the control value is taken as 0 . This indicates that for threshold sensitivity the contribution of postretinal cerebral mechanisms is smaller than that for the suprathreshold simultaneous contrast. This can also be recognized by the different slopes of the dichoptic vs. monoptic correlations in Fig. 3 ( 0.43 for the darkness induction and 0.18 for the contrast sensitivity experiments, respectively). In addition, the relative threshold vs. surround intensity function in Fig. 2B appears to saturate at lower surround intensities in the dichoptic than in the monoptic situation.

The results of the experiments described here clarify the old controversy in psychophysics as to whether visual contrast phenomena are of retinal or 
central (cerebral) origin. They indicate that, with some interindividual variation, the central contribution is about $50-60 \%$ in the case of simultaneous contrast and about $25 \%$ for threshold sensitivity. This means that in the case of simultaneous contrast, the retinal contrast is amplified by central mechanisms by a factor of $1.5-2.0$, while in the threshold situation the central amplification is about 1.25 .

As a mechanism for retinal contrast phenomena lateral neuronal interaction between adjacent retinal regions (center/surround organization of receptive fields of individual ganglion cells) as well as stray light effects have to be considered [1, 2]. As our experiments were not intended or designed to discriminate between both, we will not discuss further this aspect. As for the central contribution, an inhibitory interaction in the lateral geniculate nucleus (LGN) or the cerebral cortex could be possible. Binocular inhibitory interaction in the LGN has been observed by several authors in neurophysiological measurements in cats but is weak and essentially restricted to the receptive field center [18]. Interocular inhibition in the primary visual cortex (area 17), on the other hand, is very strong indeed [4], and could certainly contribute to lateral inhibition and thus brightness attenuation via surround mechanisms. However, the lateral extent of intracortical inhibition is limited and essentially restricted to a modular width of 1.0-1.5 mm or less [19]. This would correspond, in the foveal region, to an angular width of much less than $1^{\circ}$, whereas perceptual effects of surround induction spread over several degrees. As it is difficult to reconcile this with the limited spread of intracortical inhibition, we conclude that simultaneous brightness contrast is not only the result of lateral neuronal interactions and of adaptive gain control, but that it also involves a comparison of activity levels in adjacent regions of the visual field representation.

Our results explain why experimental evidence can be brought forward for each of the contrasting views about the location of neuronal algorithms for simultaneous contrast in the retina or the cortex [7-11]. In fact, both are true but the central contribution is much smaller than the retinal and is probably due to completely different
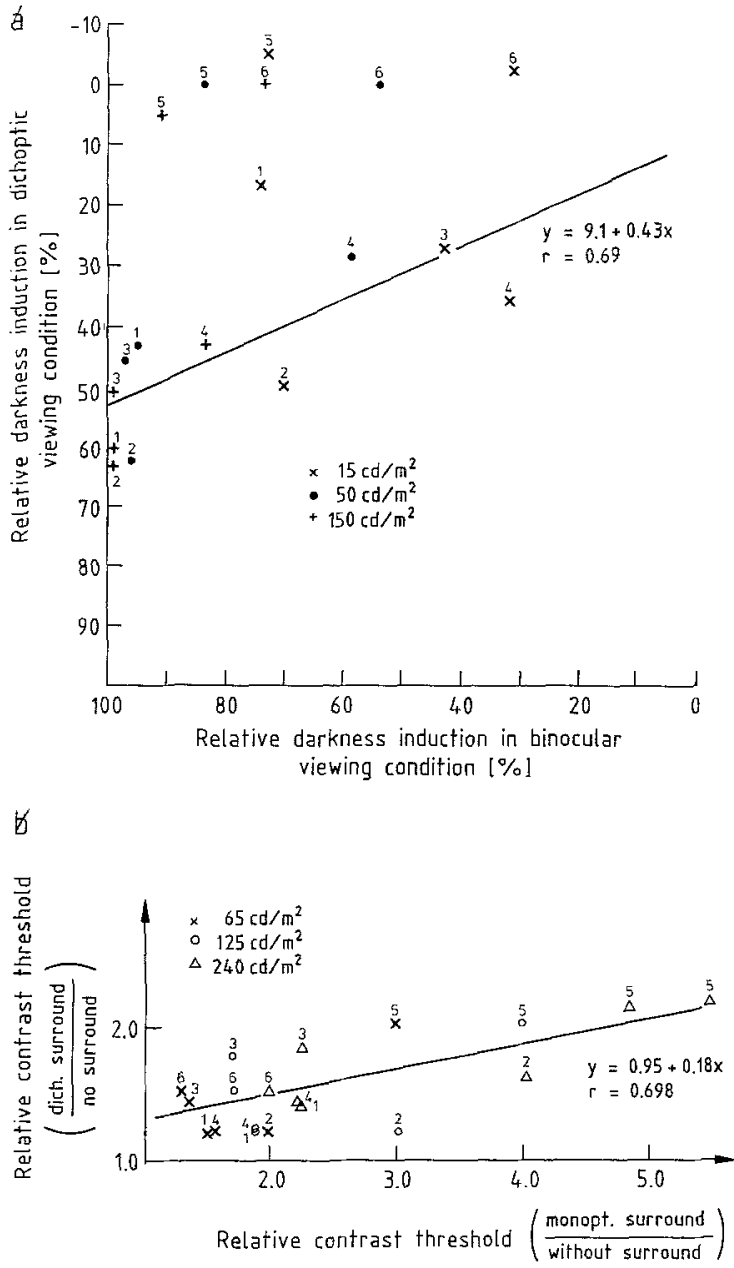

Fig. 3. Correlation between darkness induction (A) and contrast threshold increases (B) in the dichoptic and the binocular or monoptic viewing condition. A) Values from six subjects, but the correlation was calculated only for the four subjects who showed a dichoptic contrast effect (observers $1-4$ ). Symbols refer to measurements at different surround intensities as indicated, the num-

mechanisms. As brightness contrasts in circumscribed spectral regions are also involved in color contrast [20] and as weak color contrasts can also be evoked dichoptically $[8,21]$, the results of this study may be valid to color vision as well.

Received March 22 and April 20, 1990

1. Kuffler, S. W.: J. Neurophysiol. 16, 37 (1953); Baumgartner, G., Hakas, P.: Pflügers Arch. 274, 489 (1962); Ratliff, F.: Mach bands: quantitative studies on neuronal networks in the retina. bers on the symbols refer to different observers. Relative values of darkness induction as in Fig. 1B. B) Correlation between relative increase of contrast threshold in the dichoptic and the monoptic viewing situation. Symbols refer to measurements at different surround intensities as indicated, the numbers refer to the different observers

San Francisco-London-Amsterdam: Holden-Day 1965; Ratliff, F.: Proc. Am. Soc. 151, 150 (1971)

2. Walraven, J.: Vision Res. 13, 1739 (1973); Creutzfeldt, O., Crook, M., Kastner, S., Li, Chao-yi, Pei Xing: submitted

3. Singer, W., Creutzfeldt, O.: Exp. Brain Res. 10, 311 (1970); Singer, W., Pöppel, E., Creutzfeldt, O.: ibid. 14, 210 (1972)

4. Creutzfeldt, O., Ito, M.: ibid. 6, 324 (1968); Creutzfeldt, O., Kuhnt, U., Benevento, L. A.: ibid. 21, 251 (1974); Hess, R., Murata, K.: ibid. 21, 285 (1974); Sillito, A. M.: J. Physiol. (Lond.) 250, 287 (1975); Sillito, A. M., in: Cerebral Cortex, Vol. 2, p. 91 
(Jones, E. G., Peters, A., eds.). New York-London: Plenum 1984

5. Poggio, G. F., Fischer, B.: J. Neurophysiol. 40, 1392 (1977)

6. Li Chao-yi, Creutzfeldt, O. D.: Pflügers Arch. 401, 304 (1984); Creutzfeldt, O. D., Weber, H., Tanaka, M., Lee, B. B.: Exp. Brain Res. 68, 541 (1987)

7. Mach, E.: Sitzungsber. Wiener Akad. 54/2, 131 (1866); 57/2, 11 (1868)

8. Hering, E.: ibid. 68, 186; 229 (1874)

9. Helmholtz, H. v.: Handbuch der physiologischen Optik, Bd. II. Hamburg: Voss 1866

10. Land, E. H., Hubel, D. H., Livingstone, M. S., Perry, S. H., Burns, M. M.: Nature 303, 616 (1983)
11. Pöppel, E.: ibid. 320, 523 (1986)

12. Fechner, G. T.: Über einige Verhältnisse des binokularen Sehens. Leipzig: Hirzel 1860; Hering, E., in: Handbuch der gesamten Augenheilkunde, Bd. III, S. 1 (Graefe, A., Saemisch, Th., eds.). Berlin: Springer 1925

13. De Weert, Ch. M. M., Levelt, W. J. M.: Vision Res. 16, 59 (1976); LangeMalecki, B., Creutzfeldt, O., Hinse, P.: Perception 14, 587 (1985)

14. Levelt, W. M.: Br. J. Psychol. 56, 1 (1965); Engel, G. R.: Vision Res. 7, 753 (1967)

15. Lange-Malecki, B., et al., in: [13]

16. Aulhorn, E.: Monatsbl. Augenheilk. 148,540 (1966)
17. Fa. Clement Clarke, London

18. Suzuki, H., Kato, E.: J. Neurophysiol. 29, 909 (1966); Sanderson, K. I., Darian-Smith, I., Bishop, P. O.: Vision Res. 9, 1297 (1969); Sanderson, K. I., Bishop, P. O., Darian-Smith, I.: Exp. Brain Res. 13, 178 (1971); Pape, H. C., Eysel, U. T.: ibid. 61, 265 (1986)

19. Creutzfeldt, O. D.: Naturwissenschaften 64, 507 (1977); Szentagothai, J.: Exp. Brain Res., Suppl. 9, 347 (1984)

20. Creutzfeldt, O., Lange-Malecki, B., Creyer, E.: J. opt. Soc. Am. (in press)

21. Hering, E., in: Hermann's Handbuch der Physiologie Vol. III/1, S. 343 , Leipzig: Vogel 1879
NMR für Mediziner und Biologen. Strukturbestimmung, Bildgebung, invivo-Spektroskopie. Von K. H. Hausser und H. R. Kalbitzer. Berlin-Heidelberg-New York: Springer 1989. XII, 221 S., 133 Abb., DM 98, - .

Im Vorwort wird die Zielsetzung des Buches u.a. mit dem Satz charakterisiert „... haben uns bemüht, ein für Biologen und Mediziner lesbares Buch zu schreiben, das unter weitgehendem Verzicht auf mathematischen Formalismus die physikalischen Prinzipien und die typischen Möglichkeiten und medizinischen Fragestellungen und deren Lösungen der NMR allgemein verständlich herausarbeitet". Der Anlaß, ein solches Buch zu schreiben, liegt sicher in den vielen neuen Kernresonanzmethoden begründet, die in den vergangenen Jahren erfolgreiche Anwendungen im biomedizinischen $\mathrm{Be}$ reich gefunden haben. Der Anspruch, dieser Zielsetzung zu genügen, ist andererseits keine einfache Aufgabe angesichts der Vielfalt der Kernresonanzmethoden und der Tatsache, daß Mediziner und Biologen in der Regel weniger daran interessiert sein können, eine allgemeine Methodik grundlegend $\mathrm{zu}$ erlernen, sondern eine Lösung für eine aktuelle Fragestellung finden möchten. Beim Mediziner wird dies vorrangig ein diagnostisches Problem, beim Biologen eher die Grundlagenforschung betreffen. Kann diesem Anwenderkreis mit einem doch nur gut 200 Seiten starken
Buch geholfen werden? Den Versuch war es sicher wert, und es ist in der Tat so, daß es kaum Vergleichbares auf dem Büchermarkt gibt.

Interessant ist, wie Hausser und Kalbitzer die Schwerpunkte setzen. In den Kapiteln „Grundlagen der Kernresonanz" und „Die Kernresonanzspektroskopie in der Biochemie" wird auf 77 Seiten eine allgemeine Einführung in die wichtigsten Phänomene der Kernresonanz gegeben. Erst im folgenden $\mathrm{Ka}$ pitel, „Die NMR-Spektroskopie biologischer Makromoleküle“, kommen die eigentlichen biochemischen Anwendungen zum Zuge. Auf 58 Seiten werden Beispiele der ein- und zweidimensionalen Spektroskopie von Proteinen, $\mathrm{Nu}$ kleinsäuren, Polysacchariden und Lipiden besprochen. Dazwischen sind auch methodische Abschnitte, z.B. zur Mustererkennung in 2D-Spektren, eingefüigt.

Dem Titel zufolge wendet sich das Buch an Mediziner und Biologen. Diese dürften jedoch bei dem biochemisch ausgelegten ersten Teil ungeduldig werden: Erst die nachfolgenden Kapitel zu NMR-Tomographie und in-vivo-NMR decken auf 67 Seiten den NMR-Anwendungsbereich $\mathrm{ab}$, in dem weltweit Tausende von Medizinern arbeiten.

Das Buch gibt einen guten Überblick über viele aktuelle Methoden der NMR. Die ausgewählten Anwendungsbeispiele tragen zur Anschaulichkeit bei. Eher verwirrend dürfte dagegen wirken, wenn etwa cw-Spektrokopie und cwSpektrometer erläutert werden. Ebenso sind das Projektions-/Rekonstruktionsverfahren, das von Lauterbur in seiner Pionierarbeit verwendet wurde, und das 2D-FT-Bildgebungsverfahren in der ursprünglich von Kumar, Welti und Ernst vorgestellten Version sicher historische Meilensteine. Warum aber ausgerechnet die heutzutage standardmäßig in allen NMR-Tomographen eingesetzte 2D-FT-Spin-Echo-Impulssequenz nicht dargestellt wird, ist unverständlich. Vor allem bei den Abschnitten zu Tomographie und in-vivo-Spektroskopie erscheint die Auswahl der Methoden etwas zufällig und nicht so sehr von der praktischen Bedeutung her abgeleitet. Die starke Gewichtung der Methoden zur Strukturaufklärung biologischer Makromoleküle liegt dabei wohl an der Interessenlage der Autoren.

Die Darstellung des Textes ist weitgehend dem einführenden Charakter des Buches angepaßt. Allerdings sollten für Nicht-NMR-Spektroskopiker unverständliche Angaben wie „... ppm zu hohem Feld verschoben" vermieden bzw. erläutert werden. Die in der Medizin eingebürgerten Akronyme MRI und MRS werden nicht erwähnt. Hier wird dem Sprachgebrauch der Zielgruppe nicht ganz Rechnung getragen.

Das Buch ist zu empfehlen für alle, die in das biomedizinische Anwendungsgebiet der NMR neu eintreten wollen. Es 